\title{
Faktor-Faktor Yang Mempengaruhi Ibu Menyusui Tidak Memberikan ASI Secara Eksklusif Di Puskesmas Sidomulyo Kecamatan Tampan Pekanbaru
}

\author{
Maswarni 1, Wahyu Hildayanti2 \\ 1. Staff Pengajar Jurusan D III Keperawatan FMIPA dan Kesehatan \\ 2. Alumnus Jurusan D III Keperawatan FMIPA dan Kesehatan \\ Fakultas MIPA dan Kesehatan Universitas Muhammadiyah Riau
}

\begin{abstract}
Abstrak
Air susu ibu (ASI) adalah cairan putih yang dihasilkan oleh kelenjar payudara ibu melalui proses menyusui. Cakupan ASI di Indonesian masih rendah, termasuk di Kota Pekanbaru yaitu 46,81\%. ASI eksklusif menurut World Health Organization adalah memberikan hanya ASI saja tanpa memberikan makanan dan minuman lain kepada bayi sejak lahir sampai berumur 6 bulan, kecuali obat dan vitamin. Namun bukan berarti setelah pemberian ASI eksklusif selama 6 bulan pemberian ASI dihentikan, akan tetapi tetap diberikan kepada bayi sampai bayi berusia 2 tahun. Untuk memasyarakatkan pemberian ASI sejak dini diperlukan faktor-faktor pendukung yang terus-menerus untuk keberhasilan menyusui, antara lain bergantung pada peran : usia ibu, pendidikan, pekerjaan, tradisi/budaya, dukungan suami/keluarga dan petugas kesehatan. Tujuan penelitian ini adalah untuk mengetahuai faktor -faktor yang mempengaruhi ibu menyusui tidak memberikan ASI Eksklusif di Puskesmas Sidomulyo Kecamatan Tampan Pekanbaru. Teknik pengambilan sampel menggunakan accidental sampling dengan jumlah sampel 32 responden dengan bayi usia 0-6 bulan. Instrumen yang digunakan dalam penelitian ini adalah kuesioner. Teknik analisa data yang digunakan dengan analisa univariat berupa distribusi frekuensi. Hasil penelitian menunjukan usia ibu rata-rata 18-35 tahun adalah 21 responden $(65,6 \%)$ sedangkan usia 3640 adalah 11 responden (34,4\%), pengaruh pendidikan ibu diperoleh tinggi sebanyak 29 responden $(90,6 \%)$, pengaruh pekerjaan ibu diperoleh dengan data bekerja sebanyak 12 reponden $(37,5 \%)$, pengaruh pengetahuan diperoleh kurang sebanyak 27 responden $(84,4 \%)$, untuk pengaruh tradisi/budaya diperoleh ada kebiasaan 26 responden $(81,2 \%)$, untuk dukungan suami/keluarga diperoleh ada dukungan yaitu 25 responden $(78,1 \%)$ dan untuk dukungan dari petugas kesehatan diperoleh ada dukungan yaitu 24 responden $(75 \%)$.
\end{abstract}

Kata Kunci : Faktor-Faktor Yang Mempengaruhi Ibu menyusui Dalam Pemberian Asi Eksklusif

\section{Abstract}

Mother's milk (ASI) is a white liquid produced by breast milk. Coverage of breast milk in Indonesia is still low, including in the city of Pekanbaru, which is $46.81 \%$. Exclusive breastfeeding according to the World Health Organization only provides breast milk without providing food and drinks for babies from birth to 6 months, except drugs and vitamins. But that does not mean after giving exclusive breastfeeding for 6 months after the milk is released, but still given to babies until the baby receives 2 years. To promote ASI assistance from an early age, it is necessary to continue supporting factors needed to obtain assistance, including the necessary roles: maternal age, education, employment, tradition / culture, support of husband / family and health workers. The purpose of this study was to find out the factors needed by nursing mothers not to give exclusive breastfeeding at Sidomulyo Health Center, Tampan District, Pekanbaru. The sampling technique uses accidental sampling with a sample of 32 respondents with infants aged 0-6 months. The instrument used in this study was a questionnaire. The data analysis technique used with univariate analysis consists of frequency distribution. The results showed that the average maternal age of 18-35 years was 21 respondents (65.6\%) while the age of 36-40 was 11 respondents (34.4\%), the motivation of maternal education was as high as 29 respondents (90.6\%), the influence of maternal work was obtained by working data as many as 12 respondents (37.5\%), the influence of knowledge was obtained less than 27 respondents (84.4\%), for traditional / cultural interactions obtained there were 26 respondents (81.2\%), for Husband / family support was obtained by supporting 25 respondents (78.1\%) and for support from health workers, there was support for 24 respondents (75\%).

Keywords: mother, exclusive mother's milk, Factors Affecting Mother Income in Exclusive Breastfeeding 


\section{PENDAHULUAN}

ASI eksklusif adalah hanya dengan memberikan ASI saja tanpa memberikan makanan dan minuman lain kepada bayi sejak lahir sampai berumur 6 bulan, kecuali obat dan vitamin. Pemberian ASI eksklusif akan tetap diberikan kepada bayi sampai bayi berusia 2 tahun.Kandungan dalam ASI tak kalah penting, karena terdapat zat pembangun (protein, mineral), zat pengatur (vitamin, mineral, protein, air) dan zat tenaga (hidrat arang, lemak). ASI eksklusif merupakan salah satu usaha dunia untuk mempersiapkan cikal bakal penerus yang sehat sejak usia dini (WHO, 2011).

Dari 136,7 juta bayi lahir diseluruh dunia dan hanya 32,6 persen dari mereka yang disusui secara eksklusif dalam 6 bulan pertama. Sedangkan di negara industri, bayi yang tidak diberi ASI eksklusif lebih besar meninggal dari pada bayi yang diberi ASI eksklusif. Sementara di negara berkembang hanya 39 persen ibu-ibu yang memberikan ASI eksklusif kepada bayinya (UNICEF, 2013). Prevalensi ASI eksklusif di India mencapai 46 persen, di Philipina 34 persen, di Vietnam 27 persen dan di Myanmar 24 persen (Detikhealth, 2012). Riset Kesehatan Dasar (Riskesdas) 2013 menyebutkan, hanya 30,2 persen bayi umur kurang dari 6 bulan yang mendapat ASI eksklusif, angka ini turun dari tahun 2010 yang mencapai 31 persen (Riskesdas, 2010-2013). Cakupan pemberian ASI eksklusif untuk Jawa Tengah hanya sekitar 25,6 persen, menurun dibandingkan tahun 2011 yang berkisar (45,18\%) (Dinkesprovjateng, 2012).

Pemberian ASI eksklusif di Indonesia masih sangat memprihatinkan yaitu mencapai 54,3 persen. Pada tahun 2015 Millennium Development Goals (MDG's) Indonesia menargetkan penurunan sebesar 23 untuk angka kematian bayi dan balita dalam kurun waktu 2009-2015. Oleh sebab itu, Indonesia mempunyai komitmen untuk menurunkan angka kematian bayi dari 68/1.000 kelahiran hidup menjadi 23/1.000 kelahiran hidup dan angka kematian balita dari 97/1.000 kelahiran hidup menjadi 32/1.000 kelahiran hidup.Salah satu rangka menurunkan AKB, yaitu dapat dilakukan dengan pemberian ASI eksklusif (Badan Perencanaan Pembangunan Nasional, 2010).

Prevalensi hasil pencapaian program pemberian ASI Eksklusif Dinas kesehatan Kota Pekanbaru (2011) menyatakan bahwa pemberian ASI eksklusif pada bayi usia 0 - 6 bulan di Kota Pekanbaru menunjukkan penurunan berkisar 47,81 persen pada tahun 2010, dan pada tahun 2011 menjadi 46,81 persen. Dari hasil tersebut dapat di simpulkan bahwa pemberian ASI eksklusif di Kota Pekanbaru masih minim dan belum optimal di banding yang sudah di targetkan oleh Nasoinal pada tahun 2010 yaitu 80 persen. Pencapaian program pemberian ASI Eksklusif di Kota Pekanbaru yang terdiri dari 12 kecamatan adalah : Kecamatan Sukajadi 24,85 persen Tampan 23,22 persen, Lima Puluh 24,34 persen, Sail 22,90 persen, Tenayan Raya 23,55 persen, Bukit Raya 24,59persen, Pekanbaru Kota 25,61persen, Senapelan 25,52persen, Rumbai 22,94persen, Rumbai Pesisir 21,16persen, Marpoyan Damai 22,84persen, Serta Payung Sekaki 22,69 persen.

Prevalensi hasil pencapaian program pemberian ASI Eksklusif Dinas kesehatan Kota Pekanbaru (2011) menyatakan bahwa pemberian ASI eksklusif pada bayi usia 0 - 6 bulan di Kota Pekanbaru menunjukkan penurunan berkisar 47,81 persen pada tahun 2010, dan pada tahun 2011 menjadi 46,81 persen. Dari hasil tersebut dapat di simpulkan bahwa pemberian ASI eksklusif di Kota Pekanbaru masih minim dan belum optimal di banding yang sudah di targetkan oleh Nasoinal pada tahun 2010 yaitu 80 persen. Pencapaian program pemberian ASI Eksklusif di Kota Pekanbaru yang terdiri dari 12 kecamatan adalah : Kecamatan Sukajadi 24,85 persen Tampan 23,22 persen, Lima Puluh 24,34 persen, Sail 22,90 persen, 
Tenayan Raya 23,55 persen, Bukit Raya 24,59persen, Pekanbaru Kota 25,61persen, Senapelan 25,52persen, Rumbai 22,94persen, Rumbai Pesisir 21,16persen, Marpoyan Damai 22,84persen, Serta Payung Sekaki 22,69persen (Dinkes Riau, 2011).

Faktor-faktor yang mempengaruhi kegagalan ibu dalam pemberian ASI Eksklusif yaitu : Faktor Usia, Tingkat pendidikan ibu, Disebabkan karena pekerjaan, Kurangnya pengetahuan ibu tentang ASI Eksklusif, Tradisi/budaya yang berkaitan dengan pemberian ASI eksklusif, Kurangnya dukungan dari keluarga yaitu suami dan Kurangnya dukungan dari petugas kesehatan (Wawan \& Dewi , 2010).

Hasil survey awal yang dilakukan peneliti di Puskesmas Sidomulyo Kecamatan Tampan Pekanbaru pada tanggal 13 Juli 2017 menunjukkan bahwa dari 10 responden yang dilakukan penelitian bahwa ke 10 responden tersebut mengatakan bayinya kurang mendapatkan ASI Eksklusif, dari 10 responden tersebut bahwa terdapat 5 orang (50\%) tahu bagaimana pentingnya pemberian ASI Eksklusif selama 0-6 bulan pertama dan 5 orang (50\%) yang mengatakan tidak tahu pentingnya pemberian ASI Eksklusif selama 0-6 bulan pertama.

\section{METODOLOGI PENELITIAN}

Desain penelitian yang digunakan dalam penelitian ini adalah metode deskriptif, yaitu faktor - faktor ibu menyusui tidak memberikan ASI secara eksklusif .Tempat dilakukan penelitian ini yaitu di Puskesmas Sidomulyo Kecamatan Tampan Pekanbaru. Populasi dalam penelitian ini adalah seluruh ibu yang berkunjung kebagian Kesehatan Ibu dan Anak (KIA) Puskesmas Sidomulyo Kecamatan Tampan Pekanbaru.Adapun jumlah kunjungan ibu menyusui di Posyandu Hangtuah Wilayah Kerja Puskesmas Sidomulyo Kecamatan Tampan Pekanbaru pada periode bulan Juli - September 2017 sebanyak 103 ibu menyusui yang berkunjung di Posyandu Hangtuah.

Sampel dalam penelitian ini adalah sebagian dari ibu yang memiliki bayi yang mengunjungi Puskesmas Sidomulyo Kecamatan Tampan Pekanbaru dengan jumlah responden sebanyak 30 ibu. Teknik pengambilan sampel accidental sampling dimana dilakukan dengan cara kebetulan bertemu. Dalam penelitian ini instrumen yang digunakan adalah dengan kuesioner, Analisa data peneliti menggunakan analisa univariate, Analisa ini bertujuan untuk mempermudah interprestasi data ke dalam bentuk tabel dan uraian dalam bentuk teks untuk mendapatkan gambaran tentang distribusi frekuensi dari semua tabel baik independen maupun dependen. Hasil data diperoleh dari hasil penyebaran kuisioner. Menurut Sudijono (2009), dengan melihat persentase data yang dikumpulkan dan sajian dalam bentuk tabel frekuensi dan dipersentasikan dari tiap variable dengan rumus sebagai berikut :

$$
\begin{gathered}
\mathrm{P}=\frac{F}{N} X 100 \% \\
\text { Keterangan }: \\
\mathrm{P}=\text { Persentase } \\
\mathrm{F}=\text { Frekuensi }
\end{gathered}
$$

Hasil penelitian faktor - faktor yang mempengaruhi ibu menyusui tidak memberikan ASI secara eksklusif diolah dengan cara menggunakan SPSS dan di masukkan kedalam hitungan mean dengan standar objek sebagai berikut:

Pertanyaan :

$$
\begin{aligned}
& \text { Benar }=1 \\
& \text { Salah }=0
\end{aligned}
$$


Faktor yang mempengaruhi ibu dalam pemberian ASI eksklusif

: Nilai $\geq$ Mean

Faktor yang Tidak mempengaruhi ibu dalam pemberian ASI eksklusif

: Nilai < Mean

\section{HASIL DAN PEMBAHASAN}

\section{Distribusi Frekuensi Pengaruh Pengetahuan Ibu Dalam Pemberian ASI Secara Eksklusif di Puskesmas Sidomulyo, Kecamatan Tampan Pekanbaru}

Oktober 2017

\begin{tabular}{llcc}
\hline No & $\begin{array}{c}\text { Pengaruh } \\
\text { Pengetahuan }\end{array}$ & $\begin{array}{c}\text { Frekuensi } \\
\text { (f) }\end{array}$ & $\begin{array}{c}\text { Persentase } \\
\text { (\%) }\end{array}$ \\
\hline 1 & Baik & 5 & 15,6 \\
2 & Kurang & 27 & $\mathbf{8 4 , 4}$ \\
\hline \multicolumn{2}{c}{ Total } & $\mathbf{3 2}$ & $\mathbf{1 0 0}$ \\
\hline
\end{tabular}

Berdasarkan tabel 5.4 menunjukkan pengaruh pengetahuan ibu dalam pemberian ASI Secara Eksklusif di Puskesmas Sidomulyo Kecamatan Tampan Pekanbaru mayoritas kategori kurang yaitu 27 responden (84,4\%). Menurut Wawan A dan M dewi (2011) yang berjudul "faktor-faktor yang mempengaruhi pengetahuan adalah pendidikan, pekerjaan, umur, lingkungan dan sosial budaya".Pendidikan berarti bimbingan yang di berikan pada seseorang terhadap perkembangan orang lainmenujukearahcita-citatertentu yang menentukan manusia untuk berbuat dan mengisi kehidupan untuk mencapai keselamatan dan kebahagiaan. Menurut asumsi peneliti di Puskesmas Sidomulyo Kecamatan Tampan Pekanbaru pengetahuan adalah faktor pendukung ibu menyusu itidak memberikan ASI secara eksklusif

Tabel 5.5

Distribusi Frekuensi Pengaruh Tradisi/Budaya Dalam Pemberian ASI Secara Eksklusif di Puskesmas Sidomulyo, Kecamatan Tampan Pekanbaru

Oktober 2017

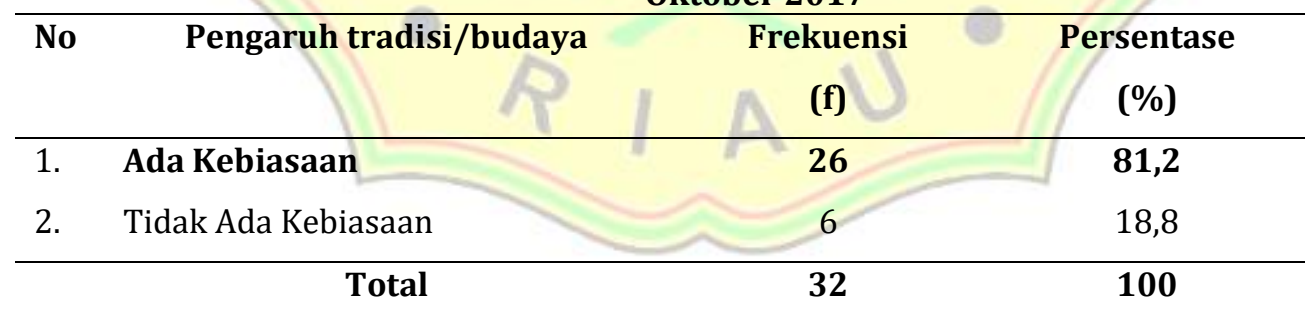

Berdasarkan tabel 5.5 menunjukkan pengaruh tradisi/budaya dalam pemberian ASI Secara Eksklusif di Puskesma Sidomulyo Kecamatan Tampan Pekanbaru mayoritas kategori ada kebiasaan yaitu 26 responden (81,2\%), Di mana masyarakat beranggapan bahwa Kolostrum atau ASI pertama adalah ASI basi sehingga harus di buang.

Menurut pendapat Irhamni, dkk (2015) yang berjudul“budaya atau kebiasaan merupakan salah satu yang mempengaruhi status kesehatan di Kelurahan Bendung Kecamatan Cilegon". Di antara kebudayaan maupun adat-istiadat dalam masyarakat ada yang menguntungkan, ada pula yang merugikan. Banyak sekali pengaruh atau yang menyebabkan berbagai aspek kesehatan di negara kita, 
bukan hanya karena pelayanan medik yang tidak memadai atau kurangnya perhatian dari instansi kesehatan, antara lain masih adanya pengaruh sosial budaya yang turun temurun masih dianut sampai saat ini. Selain itu ditemukan pula sejumlah pengetahuan dan perilaku yang tidak sesuai dengan prinsipprinsip kesehatan. Menurut asumsi peneliti budaya merupakan faktor yang mempengaruhi ibu tidak memberikan ASI secara eksklusif. Selain itu masyarakat juga beranggapan bahwa kolostrum itu tidak penting dan harus dibuang karena sudah lama sehingga basi dan dapat menyebabkan diare jika diberikan kepada bayi.

Tabel 5.6

Distribusi Frekuensi Pengaruh Dukungan suami/keluarga Dalam Pemberian ASI Secara Eksklusif di Puskesmas Sidomulyo, Kecamatan Tampan Pekanbaru Oktober 2017

\begin{tabular}{lccc}
\hline No & $\begin{array}{c}\text { Pengaruh dukungan } \\
\text { suami/keluarga }\end{array}$ & $\begin{array}{c}\text { Frekuensi } \\
\text { (f) }\end{array}$ & $\begin{array}{c}\text { Persentase } \\
\text { (\%) }\end{array}$ \\
\hline 1 & Ada Dukungan & $\mathbf{2 5}$ & $\mathbf{7 8 , 1}$ \\
2 & Tidak Ada Dukungan & 7 & 21,9 \\
\hline & Total & $\mathbf{3 2}$ & $\mathbf{1 0 0}$ \\
\hline
\end{tabular}

Berdasarkan tabel 5.6 menunjukkan pengaruh dukungan suami/keluarga dalam pemberian ASI Secara Eksklusif di Puskesmas Sidomulyo Kecamatan Tampan Pekanbaru mayoritas kategori ada dukungan yaitu 25 responden (78,1\%). Menurut Puspitasari (2011) yang berjudul "Faktor-faktor yang mempengaruhi ibu dalam memberikan ASI eksklusif,Hasil penelitian tersebut menunjukkan, bahwa salah satu bentuk dukungan keluarga berupa pemberian bantuan dalam bentuk materi seperti pinjaman uang, bantuan fisik berupa alat-alat atau lainnya yang mendukung dan membantu menyelesaikan masalah. Dalam mengatasi ketegangan kehadiran keluarga sangat penting untuk mendorong ibu dalam meningkatkan kepercayaan diri dan menstabilkan emosinya, serta memberi kan motivasi yang besar terhadap ibu yang menyusui.Dukungan keluarga mempunyai hubungan dengan suksesnya pemberian ASI eksklusif kepada bayi.

Tabel 5.7

\begin{tabular}{|c|c|c|c|}
\hline \multicolumn{4}{|c|}{$\begin{array}{c}\text { Eksklusif di Puskesmas Sidomulyo } \\
\text { Kecamatan Tampan Pekanbaru } \\
\text { Oktober } 2017\end{array}$} \\
\hline No & $\begin{array}{c}\text { Pengaruh dukungan } \\
\text { petugas kesehatan }\end{array}$ & $\begin{array}{c}\text { Frekuensi } \\
\text { (f) }\end{array}$ & $\begin{array}{c}\text { Persentase } \\
\text { (\%) }\end{array}$ \\
\hline 1 & Ada Dukungan & 24 & 75 \\
\hline 2 & Tidak Ada Dukungan & 8 & 25 \\
\hline & Total & 32 & 100 \\
\hline
\end{tabular}

Berdasarkan tabel 5.7 menunjukkan pengaruh dukungan petugas kesehatan dalam pemberian ASI Secara Eksklusif di Puskesmas Sidomulyo Kecamatan Tampan Pekanbaru mayoritas kategori ada dukungan yaitu 24 responden (75\%). Penelitian ini didukung oleh penelitian andriana(2014) yang berjudul "Hubungan Pengetahuan Sikap, Akses Pelayanan Keshatan, Jumlah sumber informasi dandukungan 
keluarga dengan pemanfaatan fasilitas persalinan yang memadai oleh ibu bersalin di Puskesmas Kawangu KabupatenSumba Timur". yang mana hasil penelitian menyimpulkan ada hubungan yang sangat kuat antara akses pelayanan kesehatan dengan pemberian ASI eksklusif. Sehingga perlu dilakukan kejangkauan akses kesehatan pelayanan kesehatan terutama sarana dan prasarana yang mendukung dalam pemberian ASI eksklusif oleh ibu bersalin serta melakukan penelitian lebih lanjut lagi. Dukungan petugas kesehatan sendiri, baik itu dokter, bidan, perawat maupun kader kesehatan, semua petugas kesehatan ini memiliki peran yang sangat penting dalam menunjang keberhasilan memberikan ASI eksklusif (IkawatidanSyafiq, 2009).

\section{KESIMPULAN}

Berdasarkan hasil penelitian yang dilakukan di Puskesmas Sidomulyo Kecamatan Tampan Pekanbaru pada tanggal 12 - 20 Oktober 2017 tentang "Faktor-Faktor Yang Mempengaruhi Ibu Menyusui Tidak Memberikan ASI Secara Eksklusif”. Maka dapat disimpulkan bahwa :

Faktor-faktor yang mempengaruhi ibu menyusui tidak memberikan ASI secara eksklusif adalah kurangnya pengetahuan reponden diduga disebabkan antara lain kurang informasi, kurang jelasnya informasi dan kurangnya kemampuan ibu untuk memahami informasi yang diterima. Karena pengaruh tradisi/budaya menyebabkan sebagian masyarakat memiliki adanya kebiasaan dan beranggapan bahwa kolostrum itu tidak penting dan harus dibuang karena sudah lama sehingga basi dan dapat menyebabkan diare jika diberikan kepada bayi.

\section{DAFTAR PUSTAKA}

Astuti.(2010). Faktor-faktor yang melatarbelakangiibumenyusuitidakmemberikan ASI secaraeksklusif. Jurnal Penelitian.

Andriana. (2014). "Hubungan Pengetahuan Sikap, Akses Pelayanan Keshatan, Jumlah sumber informasi dan dukungan keluarga dengan pemanfaatan fasilitas persalinan yang memadai oleh ibu bersalin dipuskesmas kawangu kabupaten sumba timur" . Diperoleh tanggal 6 Januari 2017.

Budiati. (2008). Asuhan Keperawatan Anak Cetakan pertama. Yogyakarta: Nuha Medika.

Douglas.(2000).Faktor-faktor yang melatarbelakangiibumenyusuitidakmemberikan ASI secaraeksklusif

Efendi. (2012). Metode Penelitian Keperawatan dan Tekhnik Analisa Data. Jakarta: Salemba Medika.

Ferry. (2009).Faktor-faktor yang melatarbelakangiibumenyusuitidakmemberikan ASI secaraeksklusif .

Firmansyah\&Mahmudah. (2012). Faktor-faktor yang melatarbelakangiibumenyusuitidakmemberikan ASIsecaraeksklusif.

Hendarto\&Pringgadini. (2008).Faktor-faktor yang melatarbelakangiibumenyusuitidakmemberikan ASI secaraeksklusif. Jurnal Penelitian.

Hidajati. (2012). "umur adalah faktor yang menentukan dalam pemberian ASI". Jakarta: Fakultas Kedokteran Universitas Indonesia. Diperoleh tanggal 26 September 2016.

Ikawati\&syafiq. (2009). Pemberian ASI Eksklusif pada Bayi Usia 0-6bulan di Puskesmas Kuranji Kota Padang. Jurnal Kesehatan Andalas.

Irhamni, dkk . (2015). "budaya atau kebiasaan merupakan salah satu yang mempengaruhi status kesehatan di Kelurahan Bendung Kecamatan Cilegon": Jurnal Universitas Esa Unggul Jakarta. 
Jannahdalamtarbiyah. (2009).Faktor-faktor yang melatarbelakangiibumenyusuitidakmemberikan ASIsecaraeksklusif.

Khairuniyah.(2004). Faktor-faktor yang melatarbelakangiibumenyusuitidakmemberikan $A S I$ secaraeksklusif. Jurnal Penelitian.

Kusumah.(2011). Metode Penelitian Keperawatan dan Tekhnik Analisa Data.

Ludin. (2010). Pemberian ASI Eksklusif pada Bayi Usia 0-6bulan.

Maas. (2004). PerilakuibudalamPemberian ASI Eksklusif Pada Bayi usia0-6 bulan di Wilayah Kerja Puskesmas Banyudono Kabupaten Boyolali. Publikasi Ilmiah : Universitas Muhammadiyah Surakarta.

Nursalam. (2004). Faktor-faktor yang melatarbelakangiibumenyusuitidakmemberikan ASIsecaraeksklusif.

Nuraini. (2013). Faktor-faktor yang melatarbelakangiibumenyusuitidakmemberikan ASIsecaraeksklusif.

Nurkhasanah.(2011). Faktor-faktor yang melatarbelakangiibumenyusuitidakmemberikan ASI secaraeksklusif. Jurnal Penelitian.

Prasetyono.(2009).Promosi Kesehatan. Jakarta: EGC

Puspitasari.(2011). "Faktor-faktor yang mempengaruhi ibu dalam memberikan ASI eksklusif".Publikasi Ilmiah : Universitas Muhammadiyah Surakarta. Diperolehtanggal 23 Februari 2016.

Siregar.(2004). "Faktor-faktor yang mempengaruhi ibu menyusui dalam pemberian ASI eksklusif".Universitas Islam Negeri Syarif Hidayatullah. Jakarta.

Tasya. (2008). "Faktor yang mempengaruhi pemberian ASI eksklusif". di Desa Pardede onan Kecamatan Balige Kabupaten Toba Samosir": Universitas Sumatera Utara. Diperoleh tanggal 19 Maret 2015.

Rusliana. (2004). Faktor-faktor yang melatarbelakangiibumenyusuitidakmemberikan ASIsecaraeksklusif.

Roesli.(2008).Faktor-faktor yang melatarbelakangiibumenyusuitidakmemberikan ASI secaraeksklusif. Jurnal Penelitian.

Rahmadhanny.(2012). Konsep dan Penulisan Riset Keperawatan. Yogyakarta : Graha Ilmu.

Setiadi.(2007). Faktor-faktor yang melatarbelakangiibumenyusuitidakmemberikan ASIsecaraeksklusif.

Soraya.(2006). "Manfaat ASI dan Menyusui”. Jakarta: Fakultas Kedokteran Universitas Indonesia

Sudijono.(2009). Metodogi Penelitian Kesehatan. Edisi Revisi., Jakarta: PT. Rineka Cipta.

Sumardjan \& soemardi dalam setiadi,dkk. (2008). Faktor-faktor yang melatarbelakangi ibu menyusui tidak memberikan ASI secara eksklusif. Jurnal Penelitian.

Utami.(2009). Faktor-faktor yang melatarbelakangiibumenyusuitidakmemberikan ASI secaraeksklusif. Jurnal Penelitian.

Walyani\&Purwoastuti. (2015). "pemberian asi eksklusif pada bayi umur 0-6 bulan di puskesmas Gilingan kecamatan banjarsari surakarta”.Universitas Sebelas Maret.

Wawan\&Dewi.(2010). "Faktor Resiko Kejadian Diare Pada Bayi. Jurnal

Wawan, A \& M, dewi. (2011). "faktor-faktor yang mempengaruhi pengetahuan adalah pendidikan, pekerjaan, umur, lingkungan dan sosial budaya”.Universitas Negeri Semarang. 